\title{
Inventário [gago] dos problemas da educação: conceitos constitutivos ou bloco de conceitos RIGEEA
}

Inventory [stammerer] of education problems: constitutive concepts or bloc of concepts RISEEE

Inventario [tartamudo] de los problemas de la educación: conceptos constitutivos o bloque de conceptos RITEEA

DOI: $10.1590 / 1809-5844201929$

\section{Gabriel Sausen Feil ${ }^{1}$}

https://orcid.org/0000-0003-3546-6874

\section{Fabiano Neu Pinto ${ }^{2}$}

https://orcid.org/0000-0003-2413-1438

${ }^{1}$ (Universidade Federal do Pampa, Campus São Borja, Programa de Pós-Graduação em Comunicação e Indústria Criativa. São Borja - RS, Brasil).

${ }^{2}$ (Universidade Federal do Rio Grande do Sul, Faculdade de Educação, Programa de Pós-Graduação em Educação. Porto Alegre - RS, Brasil).

\section{Resumo}

O artigo tem a intenção de explorar os conceitos que constituem a concepção de uma peça audiovisual produzida a partir de um projeto de pesquisa. Para isso, aponta a intenção de tal projeto; define o bloco de conceitos composto pelas noções deleuzianas de real, inventário, gagueira, encontro, estranhamento e acontecimento (bloco RIGEEA); por fim, conclui com o estabelecimento de uma articulação entre os conceitos e a linguagem audiovisual da peça, a fim de mostrar a consistência teórica da produção audiovisual. Ou seja, justifica ações, escolhas e estratégias da peça com base nos conceitos apresentados.

Palavras-chave: Inventário. Gagueira. Encontro. Estranhamento. Acontecimento.

\begin{abstract}
The article intends to explore the concepts that constitute the conception of an audiovisual piece produced from a research project. To this end, it points out the intention of such project; defines the concept block composed of deleuzian notions of real, inventory, stammering, encounter, estrangement and event (RISEEE bloc); finally concludes with the establishment of an articulation between the concepts and the audiovisual language of the piece, in order to show the theoretical
\end{abstract}


consistency of the audiovisual production. That is, it justifies actions, choices and strategies of the piece based on the concepts presented.

Keywords: Inventory. Stammering. Encounter. Estrangement. Event.

\section{Resumen}

El artículo pretende abordar los conceptos que integran el diseño de una pieza audiovisual producida a partir de un proyecto de investigación. Para eso, indica la intención de este proyecto; define un bloque de conceptos compuesto por las nociones deleuzianas de real, inventario, tartamudeo, encuentro, extrañamiento y acontecimiento (bloque RITEEA); finalmente se concluye con el establecimiento de un vínculo entre los conceptos y el lenguaje audiovisual de la pieza con el fin de demostrar la consistencia teórica de la producción audiovisual. Es decir, justifica las acciones, elecciónes y estrategias de la pieza basadas en los conceptos presentados.

Palabras clave: Inventario. Tartamudeo. Encuentro. Extrañamiento. Acontecimiento.

\section{Introdução - Sobre as intenções}

O Inventário [gago] dos problemas da educação é uma peça audiovisual produzida junto ao nosso projeto de pesquisa intitulado "Quais são os problemas da educação? — O que professores, alunos e gestores dizem!”. Neste artigo, temos a intenção de explorar os conceitos que constituem a concepção (tanto em termos de conteúdo quanto de expressão) de tal peça; conceitos devedores da filosofia de Deleuze (2006; 2004; 2003; 1997; 1992), Deleuze e Guattari (2010; 1997a; 1997b; 1996; 1995; 1992; 1977) e Deleuze e Parnet (1998).

A conjunção dos conceitos no bloco RIGEEA não é, de modo algum, estática. Não pressupõe a formação de uma totalidade unitária. Tampouco os conceitos atuam em separado, quando imbricados no compósito, pois não queremos "comprometê-los, enfraquecê-los, embotá-los ou privá-los do seu poder cortante de conjunto” (CORAZZA, 2017, p. 242). O que constitui a liga do bloco é a potência do que se passa nos espaços entre os elementos, intervalos possibilitadores de arranjos provisórios e inauditos; o resultado é processo sem finalidade, a não ser a de produzir um movimento outro daquele já instituído como natural. Com isso, queremos dizer que RIGEEA é da ordem da síncope: o canto do tordo ao entardecer é diverso dos outros cantos que visam o acasalamento ou a proteção, úteis para a conservação da espécie. Quando o pássaro canta para o sol, não há finalidade além do próprio cantar, como efetuação da potência de vida que não se resume à orgânica. Trata-se da produção ativa do nada (de imediatamente útil), como meio de evocar o acontecimento.

Quando o projeto de pesquisa se questiona sobre "quais são os problemas da educação?”, está propondo uma reflexão instigada pelas respostas que gestores, professores e alunos oferecem a tal questão. A peça audiovisual, por sua vez, documenta essas falas. Ainda que este artigo não tenha o objetivo de explorar o conteúdo das respostas, registra aqui que a pesquisa acaba por entender que as diferentes falas podem ser sintetizadas em onze problemas principais: Não saber qual é a função da educação; a irresponsabilidade e/ 
ou descompromisso da família; a falta de investimento e/ou de estrutura; a política/gestão governamental; a desvalorização e/ou o não reconhecimento do professor; a política de acesso e/ou permanência e/ou frequência; as metodologias usadas e/ou a não adaptabilidade às novas linguagens; a formação voltada para o capitalismo e/ou para a reprodução do sujeito; a falta de planejamento; a acomodação do professor; a irresponsabilidade e/ou o descaso do aluno.

Se o título da peça é Inventário [gago] é porque não tem o intuito jornalístico documental ou do debate e do confronto. Registramos as falas, mas não para buscarmos esclarecer qual é a verdadeira, quem está mais próximo do real, justamente porque as falas já são em si mesmas reais (R), e não apenas tocam ou deixam de tocar a realidade. Nesse sentido, não são as falas que são julgadas como gagas, mas é a própria peça que se imbui, por meio da elaboração de um inventário (I), de uma articulação gaga (G). O intuito é, por meio do encontro (E) de diferentes falas e cenários, o de criar estranhamentos (E) e de criar condições para a emergência de acontecimentos (A).

\section{Bloco de conceitos RIGEEA}

\section{Real}

Quando Deleuze e Guattari (2010, p. 50) tratam da ideia de que não há, de um lado, um desejo representacional e, de outro, um inventivo/afirmativo, mas que há apenas um desejo, ainda que "sob dois regimes diferentes", afirmam que "só existe uma produção, que é a do real”. Nesse sentido, o sonho, por exemplo, não é apenas a representação de um desejo reprimido, mas é a produção de um novo real, ainda que esse novo tenha sido instigado por um desejo anterior. Isto é, a nova produção até pode manter relações com o tal desejo reprimido, mas, de qualquer modo, o sonho já é uma nova realidade.

Assim, Deleuze e Guattari (2010; 1997a; 1997b; 1996; 1995) criam um conceito de real que rompe com a distinção entre real e irreal ou entre real e ficção. A ficção é real (mesmo uma mentira proposital produz sentidos) e o real é ficção (visto que a nós humanos cabe apenas criar sentidos que não são, evidentemente, naturais).

O rompimento com a distinção entre verdade e mentira já é estabelecido por Nietzsche (1978, p. 49). Falar a verdade não passa, conforme o pensador alemão, de um mentir “segundo uma convenção sólida [...], em um estilo obrigatório para todos”. Falar a verdade é, em outros termos, “mentir em rebanho” (FEIL, 2005, p. 167). O problema, no raciocínio nietzschiano, é que o modo de mentir que prospera até hoje é o socrático, que é problemático justamente porque mente como se estivesse falando a verdade. Isso significa que "a finalidade com que se mente faz diferença” (NIETZSCHE, 2011, p. 115). A mentira que agrada ao autor é a artística, entendida, por Feil (2005, p. 169), como aquela "que contamos a nós mesmos, e que recontamos todas as vezes que nos for interessante”. 
“Mentir, portanto, não é o problema” (FEIL, 2005, p. 169), pois tanto a verdade quanto a mentira - ou tanto o real quanto a ficção - são mentiras. Se o artista é "senhor sobre a verdade” (NIETZSCHE, 1978, p. 27) é, justamente, “porque, ao contrário do socrático e do cristão que pensam estar na posse de uma verdade, ele sabe que essa não passa de uma invenção, de uma ficção” (FEIL, 2005, p. 169).

A ideia de que há um real em oposição a um irreal é problemática, segundo o pensamento de Nietzsche (2011), porque nega a vida em sua definição maior, que é o movimento, a transitoriedade, a efemeridade. Ou seja, além de romper com a ideia de que há a verdade de um lado e a mentira de outro, e de então propor que somente o que podemos fazer é mentir (é no mentir que produzimos realidade), o filósofo ainda afirma que o melhor jeito é mentir tendo consciência da mentira.

Deleuze (2006, p. 122) diz que o simulacro é “uma imagem demoníaca”; na interpretação de Feil (2010, p. 181), uma imagem "destituída de semelhança, de modo que jamais podemos dizer o que é uma cópia e o que é um modelo”. Ou seja, o autor francês rompe com a ideia de que há uma espécie de hierarquia, em que, por exemplo, o motivo do sonho diz mais a realidade do que o próprio sonho, já que este seria apenas um simulacro, um esboço embaçado daquele.

Este conceito de real, portanto, implica dois delineamentos: a não distinção entre o real e o irreal ou representado e o critério da produção de sentido. Sobre o primeiro: não há a distinção entre o que pensamos de verdade e o que falamos; o que pensamos é real, mas o que falamos sobre esse pensamento é igualmente real, independentemente do fato do pensar e do falar estarem em sintonia. Sobre o segundo: se simulamos, falseamos, enganamos, estamos, ainda assim, produzindo sentidos e, portanto, fazendo realidade. O discurso é real e não apenas a expressão de uma realidade. Ou seja, quando falamos, a nossa fala é real e não simplesmente expressa o real que passa pela mente, assim como quando relatamos um sonho não estamos apenas contando algo reprimido, mas estamos produzindo uma nova realidade.

\section{Inventário}

A expressão do inventário não atende a uma perspectiva hermenêutica de circunscrição de significados. Não há aqui o interesse em dizer o que ele é ou de tratar do uso corrente do termo no âmbito jurídico. Há, sim, o propósito de tomá-lo segundo sua operatividade, enfatizando a potência de empuxo da dinâmica inventariante para a movimentação do pensamento. Destarte, o interesse está em lidar com o que o inventário faz, com os pormenores de seu funcionamento.

Assim, o ato inventariante — mais do que a simples coleta e organização de elementos a partir de um crivo — se dá como um processo inventivo. Não cunhamos o inventário engessando-o a partir de categorizações hierárquicas; nele não há centro, sua disposição 
operatória é rizomática, como a de uma toca kafkiana, por onde se entra através de qualquer extremidade, pois, de acordo com Deleuze e Guattari (1977, p. 7), "nenhuma entrada é privilegiada, mesmo se for quase um beco sem saída [...]. O princípio das entradas múltiplas impede somente a introdução do inimigo, o Significante”.

O inventário, fugitivo das investidas do Significante, cria possibilidades de encontros inusitados entre elementos heterogêneos que, convencionalmente, não estariam em contato. Arrola as diferenças em arranjos provisórios, sempre prontos ao desmonte e a recombinações outras, "cada elemento não para de variar e modificar sua distância em relação aos outros” (DELEUZE; GUATTARI, 1995, p. 42). Esse caráter deambulatório não diz respeito a um experimento que tem como fim atingir a conexão certa e verdadeira. Não se trata de um dispositivo dialético que se vale do contraditório para chegar a uma síntese apaziguadora. O inventário não tem finalidade exterior ao seu próprio processo inventivo em constante produção. A experimentação vale por si só.

Não cabe ao inventário a pretensão de neutralidade. Ele é disparado por um corte crítico, montado a partir de uma série de escolhas, que tampouco são pessoais no sentido do arbítrio da vontade de um sujeito. A figura do inventariante funciona como algo da ordem do que Deleuze e Guattari (1992, p. 86) chamam de personagem conceitual, em que “eu não sou mais eu, mas uma aptidão do pensamento para se ver e se desenvolver através de um plano que me atravessa em vários lugares. O personagem conceitual nada tem a ver com uma personificação abstrata”. É o personagem inventariante, ficcional, mas não menos real, que, dispensado do compromisso com a verdade, anda por vias que nenhum “eu” está apto a percorrer e traça o mapa do inventário. A intencionalidade do inventariante não se submete a uma lógica que reduz o múltiplo ao uno, "a diversidade ou a multiplicidade não são absolutamente coleções estéticas (como quando se diz 'um a mais', 'uma mulher a mais'), nem esquemas dialéticos (como quando se diz 'um dá dois que vai dar três')” (DELEUZE; PARNET, 1998, p. 60). Trata-se de um embuste que visa desviar a atenção do intelecto, que só consegue lidar com “isso ou aquilo”, para dar livre curso ao que se passa entre "isso e aquilo":

Pois a multiplicidade nunca está nos termos, [...] está precisamente no E. [...] O $E$ não é nem um nem o outro, é sempre entre OS dois, é a fronteira, [...] uma linha de fuga ou de fluxo, mas que não se vê [...] é sobre essa linha de fuga que as coisas se passam, os devires se fazem, as revoluções se esboçam (DELEUZE; PARNET, 1998, p. 60-61).

A expressão do inventário é como um jogo que não acaba. O que de fato importa é secundário ao arranjo das peças, que em uma disposição pouco rígida, não distingue grandes e pequenos, verdadeiros e falsos, nem se organiza a partir de propriedades intrínsecas. Tal 
configuração é propositadamente destinada ao colapso e este é condição para o funcionamento do inventário.

\section{Gagueira}

Gaguejar, em Deleuze (1997), diz respeito a empurrar a linguagem ao seu limite, elevá-la a enésima potência, produzindo uma língua estranha no interior de seu próprio regime de significação por meio da imposição de uma variação contínua. Não uma disfunção da fala, mas “um tremor que já não é psicológico, porém linguístico. Assim, fazer a própria língua gaguejar, no mais profundo do estilo, é um procedimento criador que atravessa grandes obras” (p. 66).

Deleuze (1997, p. 124-125) diz que escritores como Kafka e Beckett gaguejam ao,

inventar um uso menor da língua. [...] eles fazem a língua fugir, fazem-na deslizar numa linha de feitiçaria e não param de desequilibrá-la [...]. Um grande escritor sempre se encontra como um estrangeiro na língua em que se exprime, mesmo quando é a sua língua natal.

Não se trata de misturar outra língua a sua, mas desfamiliarizar o que está dado na língua mãe, de modo que algo nela não seja mais reconhecido, de modo a procurarmos o sentido, que parecia intrínseco, e falharmos. Trata-se de impor um tratamento à língua que, ao usarmos um termo como "cadeira”, a imagem mental imediata correspondente não mais apareça, mas, no lugar dela, uma lacuna que nos força a buscar sentido, uma "gagueira nas ideias; isso só pode se exprimir na forma de questões, que de preferência fazem calar as respostas” (DELEUZE; PARNET, 1998, p. 53).

Minorar a língua de tal modo a destituí-la de sua função comunicativa. Isso não quer dizer que se abra mão da língua maior ou se produza uma outra que a substitua. Trata-se de uma bifurcação do mesmo sistema linguístico, por meio de outro tratamento que, estando em perpétua variação, não se submete ao domínio das formas constantes.

É claro que o tratamento menor da língua não se resume a torná-la hermética e intragável e, sim, que funcione como "veneno no mel”; há algo de acessível nela, mas também uma outra coisa que não encaixa e desconcerta, algo molecular que não é possível identificar. Uma incomunicabilidade que force a invenção de uma comunicação-fluxo, destinada a uma nova sensibilidade, pois “o problema não está na comunicação, mas, especificamente, na comunicação que quer comunicar, que quer efetivamente tornar comum” (FEIL, 2005, p. 10).

Podemos dizer que distintas formas de expressão, que se estratificam e se tornam modelos dominantes, como a linguagem audiovisual, estão suscetíveis a um tratamento menor que as façam gaguejar. Godard faz do cinema "uma linha de fuga ativa, linha o tempo todo quebrada, em ziguezague, subterrânea” (DELEUZE, 1992, p. 52), com uma lógica distinta daquela que Hollywood consagrou com uma narrativa linear e acessível. 
A peça que se põe a gaguejar não está interessada em contar uma história e, ainda que se valha desse artifício, a concatenação de eventos é frouxa, sempre se pondo em condições de colapso.

\section{Encontro}

Para o pensamento deleuziano, as coisas se compõem unicamente por encontros: “um encontro é talvez a mesma coisa que um devir ou núpcias [...]. Encontram-se pessoas [...], mas também movimentos, ideias, acontecimentos, entidades” (DELEUZE; PARNET, 1998, p. 6). Um chapéu, uma bola, uma xícara, um piano, todos se compõem por encontros. Partículas (ou corpos) físicos se encontram e se formam-se. Um conceito, uma opinião, um argumento, um raciocínio, todos se compõem por encontros. Partículas (ou corpos) de pensamento também se encontram e formam-se. Ou seja, para a ideia de encontro, não há distinção entre orgânico e inorgânico.

Esse é um primeiro ponto, mas há outro: o encontro é núpcias e não casamento. Núpcias dão conta de corpos que se encontram; casamento dá conta da tentativa de forçar com que esse encontro fortuito pare de se movimentar, impedindo novos encontros. É por isso que Deleuze e Parnet (1998) colocam o encontro em oposição ao reconhecimento. Ora, é que o reconhecimento somente se torna possível quando o encontro é sacramentado, recebendo nome e sobrenome. O encontro é “esse ‘entre-dois’ das solidões” (p. 8). Há um corpo em movimento solitário, há um segundo corpo em movimento solitário e aí há, talvez, o encontro, mas não o fim da solidão.

Encontros são combinações. Na combinação de tais partículas com tais partículas, temos tal objeto ou tal ideia. Mas são combinações/coleções fortuitas, ainda que possam ser planejadas. O planejamento pode existir, mas os corpos são intensos, incontroláveis e desobedientes (do ponto de vista da lógica). "Tudo é apenas encontro no universo, bom ou mau encontro” (DELEUZE; PARNET, 1998, p. 49). Podemos experimentar combinações interessantes (no sentido de potentes) ou combinações não interessantes (quando um encontro nos enfraquece, adoece-nos).

Dentre os encontros explorados por Deleuze e Guattari (2010, p. 298-299), o mais notório é o encontro que possibilita a formação do capitalismo:

De um lado, o trabalhador desterritorializado, devindo trabalhador livre e nu, tendo para vender a sua força de trabalho; do outro, o dinheiro descodificado, devindo capital e capaz de comprá-la [...]. O encontro poderia não ter ocorrido; os trabalhadores livres e o capital-dinheiro continuariam existindo 'virtualmente' cada qual do seu lado.

Nesse exemplo, aparecem cinco elementos constitutivos do conceito de encontro: a) sejam ideias, sejam coisas, tudo se compõe por encontros; b) os corpos/partículas que ora 
se encontram são independentes; c) por isso os encontros são núpcias, são efêmeros; d) as combinações são fortuitas; e) os encontros podem potencializar alguns e enfraquecer outros.

Há ainda pelo menos um sexto elemento constitutivo. Em verdade, trata-se mais propriamente de um pressuposto; e não apenas desse conceito, mas de todo o pensamento deleuziano: a imanência da Diferença; antes, durante o depois do encontro.

Não é um termo que se torna outro, mas cada um encontra o outro, um único devir que não é comum aos dois [...]. É isso a dupla captura, a vespa E a orquídea: sequer algo que estaria em um, ou alguma coisa que estaria no outro, ainda que houvesse uma troca, uma mistura, mas alguma coisa que está entre os dois, fora dos dois (DELEUZE; PARNET, 1998, p. 6-7).

O animal se relaciona com a planta, transforma-se em seu aparelho reprodutor, mas a nova planta que surge não tem nada a ver com a vespa, apesar de esta ter participado ativamente da relação. É como assistirmos a uma palestra e sairmos de lá com uma ideia para a elaboração de um novo projeto. Criamos essa ideia em relação com o palestrante, junto com o palestrante, mas muito provavelmente (trata-se de um caso hipotético) o palestrante jamais havia imaginado essa ideia. Não se trata do funcionamento da síntese dialética, pois a nova planta (ou a nova ideia) não é devedora ou herdeira dos dois termos que se encontraram.

\section{Estranhamento}

Pensar pressupõe estranhamento. Pelo predomínio de um instinto de conservação, rebaixamos nossa potência de acontecer e, ordinariamente, relacionamo-nos com o mundo a partir de mero reconhecimento. Deleuze (2003, p. 26) diz: "Reconhecemos as coisas sem jamais as conhecermos [...]: ao aprofundamento dos encontros, preferimos a facilidade das recognições”. Quando impera o reconhecimento, instaura-se uma estabilidade aparente, uma familiaridade reconfortante; lidamos não com as coisas, mas com as imagens das coisas, clichês passíveis de reprodução em um mundo conhecido e protegido das investidas do nunca-visto do caos. Quando reconhecemos, não pensamos. Pensar trata-se, sempre, de um fora, de uma "violência original feita ao pensamento, de uma estranheza, de uma inimizade" (2006, p. 121).

Platão, utilizando-se de Sócrates, diz que a filosofia inicia com a admiração, seguido por Aristóteles, que alega que o pensamento nasce do espanto. A contradição rompe com o reconhecimento e suscita o incômodo da dúvida. Entretanto, para tais filósofos, a função do pensamento se reduz a buscar respostas racionais a fim de restaurar a paz que a admiração e o espanto afastaram, sínteses dialéticas resolvendo o embate de opostos em um encadeamento que engorda a recognição. A partir desse modelo de pensamento, passamos o tempo a tamponar os inevitáveis cortes que a potência de vida indômita opera 
na estabilidade de nosso sistema de significação, “clichês que param as conexões, secam os fluxos e substituem os cortes por uma espécie de emplastro” (DELEUZE; GUATTARI, 2010, p. 409). Entretanto, o que há é o estranho, "a relação com o não-familiar é sempre primeira” (p. 473). O fundamento, o familismo, o pequeno eu estratificado da consciência e o emplastro que tomamos como realidade última resultam de uma desaceleração das velocidades do caos que, ao ser operada, funda o reino humano, como um cubo de gelo que se forma a partir da estabilização de um fluxo de água. Assim, o cubo de gelo, em meio ao oceano sem fim, com a ilusão de solidez, esquece-se que é feito de fluxo e constrói um universo inteiro em sua superfície (um universo que é uma imagem estável do próprio oceano), depreciando as velocidades caóticas que ameaçam seus fundamentos. Reconhecer é repisar o que está dado na superfície do cubo de gelo da razão humana; estranhar é devolver o pensamento a sua potência primeira.

Assim como Platão e Aristóteles, Deleuze (2003, p. 121) também afirma que o pensamento se dá a partir de um estranhamento, da "contingência de um encontro com aquilo que força a pensar”. Porém, em vez da busca por arrefecimento através de uma síntese apaziguadora, o ato de pensar, em Deleuze, afirma o estranho, o paradoxo, e utiliza o empuxo do encontro com o fortuito do mundo para elevar o pensamento ao máximo de sua potência com nenhuma outra finalidade além do aumento da própria potência de pensar. No lugar da familiaridade de uma imagem do pensamento a tamponar os cortes, rebaixando a vida ao interromper os fluxos, a suspensão de sentido de um pensamento sem imagem, que não mais reconhece, mas se põe a criar.

\section{Acontecimento}

Sobre a sua natureza: acontecimentos são hecceidades, “quer dizer, individuações sem sujeito” (DELEUZE; GUATTARI, 1995, p. 8); em outros termos, são absolutamente únicos e desprovidos de subjetividades. Tradicionalmente, as noções de sujeito/subjetividade estão associadas às de individualidade/singularidade; nesse sentido, considera-se que a singularidade é resultado do fato de cada um ter a sua subjetividade. Não é disso que se trata aqui! Um acontecimento é uma hecceidade porque é absolutamente singular/ individual (não se repete sem se diferenciar), mas é, ao mesmo tempo, desprovido de subjetividades, qualidades, identidades. A subjetividade se expressa por representações, por sistemas codificadores; o acontecimento é anterior ou posterior a isso (melhor dizendo, fica sempre fora disso ou entre isso): entre "os sujeitos determinados, [...] [há] um jogo natural de hecceidades, graus, intensidades, acontecimentos, acidentes, que compõem individuações, inteiramente diferentes daquelas dos sujeitos bem formados que as recebem” (1997a, p. 32). A individuação em questão é da vida e não “do sujeito que a leva ou a suporta” (p. 41-42).

Sobre o seu modo de captura: quem capta melhor aspectos subjetivos são aqueles mais integrados aos sistemas representacionais, mais habituados com os códigos 
estabelecidos; por outro lado, “acontece então de pessoas muito limitadas ou muito velhas captarem o acontecimento melhor do que os mais avançados homens políticos” (DELEUZE; GUATTARI, 1996, p. 87). É que um acontecimento não tange o código, pelo contrário, tange o indizível, o inexplicável. Torna-se expressão apenas via recursos neutros ao código. "Maio de 68 é a mesma coisa: todos aqueles que julgavam em termos de macropolítica nada compreenderam do acontecimento, porque algo de inassinalável escapava” (p. 87).

Sobre a sua temporalidade: o tempo do acontecimento também não é o mesmo que dá ritmo à vida do sujeito: "Aion, que é o tempo indefinido do acontecimento, a linha flutuante que só conhece velocidades [...]. E Cronos, ao contrário, o tempo da medida, que fixa as coisas e as pessoas, desenvolve uma forma e determina um sujeito” (DELEUZE; GUATTARI, 1997a, p. 42). No funcionamento de Aion há apenas o instante; no funcionamento de Cronos há o passado, o presente e o futuro. No segundo funcionamento, um fato ocorrido se associa a outros fatos já ocorridos, ou que estão ocorrendo ou ainda que estejam sendo projetados, pois é assim que um objeto ganha história ou que um indivíduo se torna sujeito: acumulando significados num processo que tem início, meio e fim, de modo que aquilo que ocorre nesse processo é delegado às partículas que mais ou menos compõem aquele objeto ou indivíduo. No primeiro funcionamento, um acontecimento diz respeito unicamente ao momento: acontece e é tudo!

Sobre o fato de romper com a oposição orgânico x inorgânico: um acontecimento não é da lógica do planejamento, pelo contrário, é acidental. Isso não significa que nada tenha a ver com seres humanos. Tem, mas justamente quando estes deixam de ser. Não há diferença entre o modo com que se forma e deforma uma coisa ou um sujeito:

Você é [...] um conjunto de velocidades e lentidões entre partículas não formadas [...]. Você tem a individuação de um dia, de uma estação, de um ano [...]; de um clima, de um vento, de uma neblina, de um enxame, de uma matilha [...]. É o próprio lobo, ou o cavalo, ou a criança que param de ser sujeitos para se tornarem acontecimentos (DELEUZE; GUATTARI, 1997a, p. 42-43).

A diferença que há entre uma coisa e outra é apenas uma diferença de velocidades. Velocidades menores para as partículas que estão compondo uma forma, velocidades maiores para as partículas suspensas caoticamente. Há o acontecimento quando a forma acelera em diluição.

Sobre a sua expressão via verbo no infinitivo e via nome próprio: segundo Deleuze e Guattari (1997a, p. 44-45), o verbo no infinitivo expressa o acontecimento em si: "cortado” é uma qualidade, mas “cortar” é o ato da transgressão da forma; é o testemunho ao vivo do desfazer. O nome próprio, por sua vez, é um recurso da linguagem que acaba por guardar o 
acontecimento; reúne um conjunto de efeitos e expressa-o: “Furacão Katrina” é um nome próprio para guardar o conjunto dos efeitos produzidos por um acontecimento.

Sobre o seu efeito: o acontecimento "faz apelo a um povo em vez de se tomar por um ministério” (DELEUZE; GUATTARI, 1997b, p. 40). Em outros termos, o acontecimento coloca em variação e segue em variação; não se trata de um empreendimento que transforma para, finalmente, estabilizar-se.

Sobre a sua imperceptibilidade: Deleuze (2004, p. 181) diz que Nietzsche se refere a "pequenos acontecimentos silenciosos, que são como a formação de novos mundos”. O acontecimento não é revolucionário ao modo dos famosos revolucionários; ele revoluciona nos pormenores.

Sobre a sua relação com os estoicos: Deleuze e Parnet (1998, p. 52) afirmam o acontecimento como "uma espécie de vapor incorporal que já não consiste em qualidades, em ações, nem paixões”. O acontecimento sobrevoa nas superfícies dos corpos, o que não significa que não seja real; pelo contrário, é real, ainda que não seja da ordem do ser: os acontecimentos "participam, antes, de um extra-ser que envolve o que é: 'avermelhar', 'verdejar', 'cortar', 'morrer', 'amar'...”. Ou seja, o acontecimento não está num mundo distinto do mundo do ser, mas deste diferencia-se, sobretudo, em termos de velocidade. São os estoicos que saem da lógica da separação "entre o sensível e o inteligível”, "entre a alma e o corpo" e afirmam o funcionamento das formas de um lado e do informado do outro: "as misturas, as causas, almas e corpos, ações e paixões, qualidades e substâncias, por um lado, e, por outro, os acontecimentos ou os Efeitos incorporais impassíveis, inqualificáveis, infinitos que resultam dessas misturas”. Considerar como real apenas o lado dos corpos não passa de um hábito e cabe "ao verbo ser, como uma tara [pretensamente] original, remeter a um Eu” e aí sim figuramos no universo das qualidades representacionais.

Precisamos entender que "o acontecimento é sempre produzido por corpos que se entrechocam, se cortam ou se penetram” (DELEUZE; PARNET, 1998, p. 53), mas que o efeito disso "não é da ordem dos corpos”. "Sim, o morrer engendra-se em nossos corpos, produz-se em nossos corpos, mas chega de Fora, singularmente incorporal, e fundindo-se sobre nós como a batalha que sobrevoa os combatentes”. Se nosso corpo se decompõe é porque está, constantemente, em contato com forças de fora, que o fazem vacilar, mexer, dissolver. "A ferida é algo que recebo em meu corpo, em tal lugar, em tal momento, mas há também uma verdade eterna da ferida como acontecimento impassível, incorporal. 'Minha ferida existia antes de mim, nasci para encarná-la””. As peças/partículas que compõem a ferida preexistem àquela pele, assim como pós existem também. Corpos ou incorpóreos, sujeitos ou simples matérias, tudo "é uma variação atmosférica, uma mudança de cor, uma molécula imperceptível, uma população discreta, uma bruma ou névoa” (p. 54), e o acontecimento é o ato ou efeito de montar e desmontar, formar e deformar. 


\section{Considerações - Como cada conceito funciona na peça}

\section{Real (Pressuposto)}

A peça documenta o que pessoas envolvidas diretamente ao setor educacional de São Borja falam a partir do que julgam ser, atualmente, os problemas da educação. Mas isso não significa que o objetivo implique buscar os verdadeiros problemas, pois não se trata de uma peça metalinguística, que separa as verdadeiras falas das falsas. Isso, justamente, por conta do conceito de real pressuposto:

- As falas já são em si mesmas reais e não apenas tocam ou deixam de tocar a realidade;

- Se o entrevistado mente, engana-se ou fala sem consistência, ainda assim se trata de uma fala real; ainda envolve a produção de sentido;

- Assim, a peça não simplesmente apresenta diferentes reais, como, e sobretudo, produz um real, registra um real.

\section{Inventário ([des]Estrutural)}

Em função do nosso entendimento acerca do conceito de inventário,

- Os problemas são agrupados a partir de um movimento que possibilita que a peça possa ser dividida e, inclusive, separada, mas não ao estilo de capítulos, e sim de aforismos (no sentido de que cada parte possa ser vista de modo independente e fora da sequência, ainda que o todo também construa um sentido - ao estilo da escrita fragmentária);

- O inventário, além de ser dos problemas, também acaba sendo dos cenários educacionais: imagens e sons da paisagem educacional compõem a peça. Uma composição disjuntiva, já que imagens e sons não se juntam numa relação ilustrativa; ao contrário, são manipulados a partir da "lógica” da gagueira;

- A construção é aberta. Os entrevistados são instigados com uma única pergunta: “quais são os problemas da educação?”. Uma pergunta absolutamente ampla, justamente, para permitir que cada entrevistado direcione a sua fala para aquilo que lhe acomete. Nesse sentido, quem elenca os problemas são os próprios entrevistados;

- Não implica uma referência anterior; ou seja, os agrupamentos são inventariados pelas próprias falas dos entrevistados.

\section{Gagueira ([des]Estrutural)}

Não são as falas que são julgadas como gagas, mas é a própria peça audiovisual que se imbui de uma articulação gaga. 
- A intenção é registrar o acontecimento, de modo que isso não implica o oferecimento de respostas;

- $\quad$ Não há um narrador. A peça não conduz a uma resposta; não assume uma postura determinada em prol de uma mensagem de fundo;

- $\quad$ O conteúdo da fala do entrevistado não precisa condizer com a expressão da peça: esta não assume, em termos de expressão, o conteúdo da fala do entrevistado (alguém fala que o problema está na estrutura da escola e, de imediato, a câmera capta uma rachadura da parede — isso não ocorre).

\section{Encontro ([des]Estrutural)}

A peça busca proporcionar encontros. As diferentes falas tomadas isoladamente produzem um sentido, mas, uma vez colecionadas/agrupadas, produzem outro.

- $\quad$ O encontro das diferentes falas se dá por núpcias e não por casamento. Núpcias não são sintéticas (como na lógica dialética) e nem hereditárias (como na lógica do DNA), mas são relações que formam um corpo sem abandonar a solidão. Isto é, partículas que montam uma forma, mas que seguem pulsantes;

- O encontro não possibilita, ao público, reconhecimento ou sensação deidentificação (ao menos não de modo proposital), mas possibilita uma experiência;

- As combinações/coleções proporcionadas pelo encontro são fortuitas, e, por isso, podem ou não serem interessantes, podem ou não funcionar.

\section{Estranhamento (Efeito)}

O inventário audiovisual lida com o estranhamento de dois modos distintos:

- Como procedimento de montagem: considerando que a produção do inventário não dá-se, num primeiro momento, sem a interferência de pressupostos arraigados em nossa própria organização enquanto sujeitos — pois, por mais que tenhamos um espaço vazio diante de nós para o arranjo das peças, somos povoados por imagens e por modos de fazer naturalizados e, por isso, dominantes —, o processo de montagem constitui-se, antes de tudo, em um embate contra o clichê, esse emplastro resultante de um vício de pensamento calcado na dialética e na vontade de verdade. De início, portanto, há um procedimento de desfamiliarização: é a raspagem do clichê, o deslocamento do comum, o fazer o inventário gaguejar;

- Como efeito da montagem: não estando a peça configurada com a finalidade de comunicar, mas de proporcionar encontros inusitados entre as falas, é presumível uma violência às faculdades do intelecto. Porém, o inventariante não se ocupa com a reação de um possível receptor; ele arma as peças do dispositivo e lança a flecha, de modo que o que acontece depois escapa do seu controle. 


\section{Acontecimento (Efeito)}

A peça busca aproximar as diferentes falas na expectativa de que, com os encontros, algo aconteça.

- A elaboração da peça pode criar condições favoráveis à emergência de acontecimentos, mas não pode prevê-los. Trata-se de um efeito incontrolável;

- O acontecimento é da ordem do pormenor e não da identificação e do reconhecimento; então, não é intenção que o público identifique acontecimentos ou se identifique com eles. Conforme já dissemos, a peça busca estranhar, não ilustrar;

- O acontecimento não está nesta ou naquela cena, mas está sobrevoando as superfícies, em suspensão.

Isso não se trata daquele já conhecido esforço de abandonar todos os formatos para fazer algo novo. Não se trata do disparate "vamos fazer algo diferente”. É verdade que não queremos, com a peça, seguir os formatos já consagrados (usarmos técnicas de persuasão e/ ou de facilitar a vida do público, tais como "usar poucos textos porque ninguém tem paciência para ler”), mas não significa que queiramos abrir mão de todas as linhas. Os próprios Deleuze e Guattari (1997a, p. 141), quando tratam da música, falam sobre isso:

O mesmo equívoco que se encontra na valorização moderna dos desenhos de criança, dos textos loucos, dos concertos de ruídos. Acontece [...] de se exagerar, opera-se com um emaranhado de linhas ou de sons; mas então, em vez de produzir uma máquina cósmica, capaz de ‘tornar sonoro', se recai numa máquina de reprodução, que [...] apaga todas as linhas, uma confusão que apaga todos os sons. Pretende-se abrir a música a todos os acontecimentos, [...] mas o que se reproduz finalmente é a confusão que impede todo o acontecimento [...]. Tornamos vago um conjunto, em vez de definir o conjunto vago pelas operações de consistência [...] que incidem sobre ele.

O grande desafio é, precisamente, encontrar esse grau de consistência; essa medida que fica entre os formatos codificados e o puro caos. Pois se por um lado não queremos os formatos estabelecidos, por outro também não queremos a incomunicabilidade proposital. E se se trata de um grande desafio é porque a tal medida certa é móvel, é traiçoeira, as doses dependem sempre de cada experiência.

\section{Referências}

CORAZZA, S. M. Ensaio sobre EIS AICE: proposição e estratégia para pesquisar em educação. Educação e Filosofia, Uberlândia, v. 31, n. 61, p. 233-262, jan./abr. 2017. 
DELEUZE, G. Conversações. Rio de Janeiro: 34, 1992.

DELEUZE, G. Crítica e Clínica. São Paulo: 34, 1997.

DELEUZE, G. Proust e os signos. Rio de Janeiro: Forense Universitária, 2003.

DELEUZE, G. A gargalhada de Nietzsche. In: DELEUZE, G. A ilha deserta e outros textos - Textos e entrevistas (1953 - 1974). São Paulo: Iluminuras, 2004.

DELEUZE, G. Diferença e repetição. Rio de Janeiro: Graal, 2006.

DELEUZE, G.; GUATTARI, F. Kafka: por uma literatura menor. Rio de Janeiro: Imago, 1977.

DELEUZE, G.; GUATTARI, F. O que é a filosofia? Rio de Janeiro: 34, 1992.

DELEUZE, G.; GUATTARI, F. Mil platôs: capitalismo e esquizofrenia, vol. 1. Rio de janeiro: 34, 1995.

DELEUZE, G.; GUATTARI, F. Mil platôs: capitalismo e esquizofrenia, vol. 3. Rio de Janeiro: 34, 1996.

DELEUZE, G.; GUATTARI, F. Mil platôs: capitalismo e esquizofrenia, vol. 4. São Paulo: 34, 1997a.

DELEUZE, G.; GUATTARI, F. Mil platôs: capitalismo e esquizofrenia, vol. 5. São Paulo: 34, 1997b.

DELEUZE, G.; GUATTARI, F. O anti-Édipo: capitalismo e esquizofrenia 1. São Paulo: 34, 2010.

DELEUZE, G.; PARNET, C. Diálogos. São Paulo: Escuta, 1998.

FEIL, G. S. Comunicação e fuga: por uma educação-fluxo. 2005. 203 f. Dissertação (Mestrado em Educação das Ciências) - Universidade Regional do Noroeste do Estado do Rio Grande do Sul, Ijuí, 2005.

FEIL, G. S. O simulacro e o biografema - de A a Z. In: CORAZZA, S. M. (Org.). Fantasias de escritura: filosofia, educação, literatura. Porto Alegre: Sulina, 2010, p. 79-91.

NIETZSCHE, F. Sobre verdade e mentira no sentido extra-moral. In: NIETZSCHE, F. Obras incompletas / Friedrich Nietzsche. São Paulo: Abril Cultural, 1978.

NIETZSCHE, F. O anticristo: maldição contra o cristianismo. Porto Alegre: L\&PM, 2011.

\section{Gabriel Sausen Feil}

Professor Associado da Universidade Federal do Pampa. Na graduação, atua no Curso de Comunicação Social - Publicidade e Propaganda (desde 2009); na pós-graduação, atua no Mestrado em Comunicação e Indústria Criativa (desde 2017). Doutor em Educação pela Universidade Federal do Rio Grande do Sul (2009); mestre em Educação nas Ciências pela Universidade Regional do Noroeste do Estado do Rio Grande do Sul (2005); graduado em Comunicação Social - Publicidade e Propaganda pela mesma Universidade (2004). Líder do Grupo de Pesquisa t3xto, coordena a Linha Experimentações filosóficas em comunicação-educação-literatura, o projeto de pesquisa Atividades criativas-máquina de guerra e o projeto de extensão Happy hour do t3xto. Interessa-se pelos pensamentos de Nietzsche, Barthes, Deleuze e Foucault; pelas literaturas de Sade, SacherMasoch, Dostoiévski, Blake, Kafka, Bataille, Bukowski e Kerouac. E-mail: gabriel.sausen.feil@ gmail.com. 


\section{Fabiano Neu Pinto}

Mestrando em Educação, na Linha de Pesquisa Filosofias da Diferença e Educação, pela Universidade Federal do Rio Grande do Sul; especialista em Atividades Criativas e Culturais pela Universidade Federal do Pampa (2016); bacharel em Comunicação Social - Publicidade e Propaganda pela Universidade Federal do Pampa (2013). Pesquisador no Grupo de Pesquisa t3xto. E-mail: f.neu@ hotmail.com.

Recebido em: 09.02.2017

Aprovado em: 31.05.2019 